\title{
Akad-Akad di dalam Asuransi Syariah
}

\author{
Junaidi Abdullah \\ Institut Agama Islam Negeri Kudus \\ joen3d1@yahoo.com
}

\begin{abstract}
Human life is full of risks. There is a risk of loss, accident and even the risk of death. To prepare for these risks, a sense of security is needed through coverage.

These coverage is through Islamic insurance. Sharia Insurance (Ta'min, Takaful or Tadhamun) is an effort to protect and help one another among a number of people / parties through investments in the form of assets and / or tabarru 'which provide a pattern of return to face certain risks through an appropriate contract (agreement) with sharia.

The contracts that are attached to Islamic insurance are the contract of contract and tabarru 'contract, while the contract that follows the contract of tijarah and the tabarru contract is the Mudharabah Musytarakah agreement, Mudharabah agreement and Wakalah bil Ujrah agreement.
\end{abstract}

Keywords: Insurance, Contract

\begin{abstract}
Abstrak
Kehidupan manusia itu penuh resiko. Ada resiko berupa kehilangan, kecelakaan bahkan resiko kematian. Untuk mempersiapkan resiko-resiko tersebut, maka diperlukan rasa aman melalui pertanggungan-pertanggungan.

Pertanggungan-pertanggungan tersebut melalui asuransi syariah. Asuransi Syariah (Ta'min, Takaful atau Tadhamun) adalah usaha saling melindungi dan tolong-menolong di antara sejumlah orang/pihak melalui investasi dalam bentuk aset dan/atau tabarru' yang memberikan pola pengembalian untuk menghadapi resiko tertentu melalui akad (perikatan) yang sesuai dengan syariah.

Akad-akad yang melekat pada asuransi syariah adalah akad tijarah dan akad tabarru', sedangkan akad yang mengikuti akad tijarah maupun akad tabarru' adalah akad Mudharabah Musytarakah, akad Mudharabah dan akad Wakalah bil Ujrah.
\end{abstract}

Kata Kunci : Asuransi, Akad

\section{PENDAHULUAN}

Manusia adalah makhluk hidup yang mempunyai perjalanan hidup yang berbeda antara satu sama lainnya. Perbedaan itu bisa dilihat dari kekayaan, tingkat pendidikan kesehatan maupun kematian yang dialaminya. Ada yang kaya dan ada yang miskin, ada yang berpendidikan rendah dan ada yang berpendidikan tinggi, ada yang selalu merasakan nikmat kesehatan dan ada pula yang merasakan nikmat sakit, bahkan ada 
yang mengalami kematian pada masa mudanya dan ada yang mengalami kematian pada umur tuanya.

Resiko-resiko yang terjadi ketika mempunyai harta yang melimpah adalah musnahnya harta tersebut dikarenakan hilang, kebakaran atau karena sebab yang lainnya. Resiko kesehatan yang diakibatkan munculnya penyakit-penyakit yang akan dialami manusia. Kemudian resiko kematian yang bisa diakibatkan karena penyakit maupun kecelakaan.

Namun, resiko-resiko tersebut di atas tidak dapat diprediksi atau diperkirakan kapan akan menimpa pada diri seseorang. Maka untuk memproteksi atau menyiapkan resiko-resiko yang mungkin akan menimpa manusia dibutuhkanlah pertanggungan-pertanggungan yang memberikan kenyamanan pada diri manusia terdsebut. Pertanggungan atau saling menanggung tersebur dinamakan asuransi.

Asuransi pada hakikatnya merupakan persiapan yang dibuat oleh seseorang untuk menghadapi kerugian atau musibah yang tidak dapat diduga atau dipredikasi. Apabila kerugian itu menimpa seseorang tersebut, maka kerugian itu akan ditanggung bersama atau oleh perusahaan asuransi.

Asuransi adalah perjanjian antara dua pihak, yaitu perusahaan asuransi dan pemegang polis, yang menjadi dasar bagi penerimaan premi oleh perusahaan asuransi sebagai imbalan untuk :

1. Memberikan penggantian kepada tertanggung atau pemegang polis karena kerugian, kerusakan, biaya yang timbul, kehilangan keuntungan, atau tanggung jawab hukum kepada pihak ketiga yang mungkin diderita tertanggung atau pemegang polis karena terjadinya suatu peristiwa yang tidak pasti.

2. Memberikan pembayaran yang didasarkan pada meninggalnya tertanggung atau pembayaran yang didasarkan pada hidupnya tertanggung dengan manfaat yang besarnya telah ditetapkan dan/atau didasarkan pada hasil pengelolaan dana (Undang Undang Nomor 40 tahun 2014 tentang Perasuransian).

Sebagai ummat islam yang terbesar dan terbanyak di Indonesia, tentu ketika menjalankan kehidupannya selalu berdasarkan pedomanpedoman yang diajarkan dalam Alqur'an maupun Hadis. Termasuk asuransi merupakan salah satu ajaran dalam Islam yang berdasarkan pada sumber hukum Islam. Asuransi yang sesuai dengan hukum Islam adalah asuransi syariah.

Asuransi Syariah (Ta'min, Takaful atau Tadhamun) adalah usaha saling melindungi dan tolong-menolong di antara sejumlah orang/pihak melalui investasi dalam bentuk aset dan / atau tabarru' yang memberikan 
pola pengembalian untuk menghadapi resiko tertentu melalui akad (perikatan) yang sesuai dengan syariah (Fatwa DSN No. 21/DSNMUI/X/2001 tentang Pedoman Umum Asuransi Syari'ah).

Ketika seseorang ikut dalam asuransi syari'ah pada perusahaan asuransi akan diikat dengan akad. Akad inilah yang bisa menjadikan halal dan haramnya sebuah asuransi. Yang dimaksud Akad adalah perjanjian tertulis yang memuat kesepakatan tertentu, beserta hak dan kewajiban para pihak sesuai prinsip syariah (Peraturan Menteri Keuangan Nomor 18/PMK.010/2010 Tentaang Penerapan Prinsip Dasar Penyelenggaraan Usaha Asuransi Dan Usaha Reasuransi dengan Prinsip Syariah).

\section{KAJIAN LITERATUR Pengertian Asuransi Syariah}

Asuransi dalam bahasa Arab disebut at-ta'min. Penanggung disebut musta'min dan yang tertanggung disebut mu'amman lahu atau musta'min. At-ta'min diambil dari kata amana yang memiliki arti perlindungan, ketenangan, rasa aman dan bebas dari rasa takut. Secara etimologis berarti menjamin atau saling mennggung (Muhamad Syakir Sula, 2004 : 31).

Sedangkan asuransi menurut Undang Undang nomor 40 tahun 2014 tentang Perasuransian, yang dimaksud dengan asuransi adalah perjanjian antara dua pihak, yaitu perusahaan asuransi dan pemegang polis, yang menjadi dasar bagi penerimaan premi oleh perusahaan asuransi sebagai imbalan untuk :

1. Memberikan penggantian kepada tertanggung atau pemegang polis karena kerugian, kerusakan, biaya yang timbul, kehilangan keuntungan, atau tanggung jawab hukum kepada pihak ketiga yang mungkin diderita tertanggung atau pemegang polis karena terjadinya suatu peristiwa yang tidak pasti

2. Memberikan pembayaran yang didasarkan pada meninggalnya tertanggung atau pembayaran yang didasarkan pada hidupnya tertanggung dengan manfaat yang besarnya telah ditetapkan dan/atau didasarkan pada hasil pengelolaan dana (Pasal 1 Undang Undang Nomor 40 tahun 2014 tentang Perasuransian).

Berdasarkan fatwa Dewan Syari'ah Nasional No. 21/DSNMUI/X/2001, bahwa asuransi syari'ah (ta'min, takaful, tadhamun) adalah usaha saling melindungi dan tolong menolong di antara sejumlah orang melalui investasi dalam bentuk aset-aset dan atau tabarru', yang memberikan pola pengembalian untuk menghadapi resiko bahaya tertentu melalui akad (perikatan) yang sesuai dengan syari'ah.

Sedangkan dalam ensiklopedia Hukum Islam yang dikutip Hasan Ali disebutkan bahwa asuransi syariah adalah transaksi perjanjian antara dua pihak, pihak yang satu berkewajiban membayar iuran dan pihak yang 
lain berkewajiban memberikan jaminan sepenuhnya kepada pembayar iuran jika terjadi sesuatu yang menimpa pihak pertama sesuai dengan perjanjian yang dibuat (Hasan Ali, 2004 : 58).

Selanjutnya menurut Undang Undang nomor 40 tahun 2014 ytentang Perasuransian, yang dimaksud dengan Asuransi Syariah adalah kumpulan perjanjian, yang terdiri atas perjanjian antara perusahaan asuransi syariah dan pemegang polis dan perjanjian di antara para pemegang polis, dalam rangka pengelolaan kontribusi berdasarkan prinsip syariah guna saling menolong dan melindungi dengan cara :

1. Memberikan penggantian kepada peserta atau pemegang polis karena kerugian, kerusakan, biaya yang timbul, kehilangan keuntungan, atau tanggung jawab hukum kepada pihak ketiga yang mungkin diderita peserta atau pemegang polis karena terjadinya suatu peristiwa yang tidak pasti

2. Memberikan pembayaran yang didasarkan pada meninggalnya peserta atau pembayaran yang didasarkan pada hidupnya peserta dengan manfaat yang besarnya telah ditetapkan dan/atau didasarkan pada hasil pengelolaan dana (Pasal 1 Undang Undang Nomor 40 tahun 2014 tentang Perasuransian).

Selanjunya yang dimaksud dengan prinsip syariah adalah prinsip hukum Islam dalam kegiatan perasuransian berdasarkan fatwa yang dikeluarkan oleh lembaga yang memiliki kewenangan dalam penetapan fatwa di bidang syariah (Pasal 1 Undang Undang Nomor 40 tahun 2014 tentang Perasuransian).

Asuransi berdasarkan prinsip syariah adalah usaha saling tolong menolong (ta'awuni) dan melindungi (takafuli) di antara para peserta melalui pembentukan kumpulan dana (Dana Tabarru') yang dikelola sesuai prinsip syariah untuk menghadapi risiko tertentu (Peraturan Menteri Keuangan Nomor 18/PMK.010/2010 Tentaang Penerapan Prinsip Dasar Penyelenggaraan Usaha Asuransi Dan Usaha Reasuransi dengan Prinsip Syariah).

Dari beberapa pengertian asuransi syariah di atas, maka asuransi syariah merupakan praktek tanggung menanggung diantara peserta untuk mendapatkan rasa aman, nyaman untuk menghadapi resiko yang kemungkinan menimpa mereka berdasarkan prinsip-prinsip syariah.

Sedangkan yang berhak untuk membuat fatwa-fatwa yang berkaitan dengan asuransi syariah adalah Majelis Ulama Indonesia melalui Dewan Syariah Nasionalnya. 


\section{Dasar Hukum Asuransi Syariah}

1. Alquran

a. Firman Allah tentang perintah mempersiapkan hari depan:

"Hai orang yang beriman! Bertaqwalah kepada Allah danhendaklah setiap diri memperhatikan apa yang telah dibuatuntuk hari esok (masa depan). Dan bertaqwalah kepada Allah. Sesungguhnya Allah Maha Mengetahui apa yang kamukerjakan" (QS. al-Hasyr [59]: 18).

b. Firman Allah tentang prinsip-prinsip bermu'amalah, baik yang harus ilaksanakan maupun dihindarkan, antara lain :

"Hai orang-orang yang beriman tunaikanlah akad-akad itu Dihalalkan bagimu binatang ternak, kecuali yang akan dibacakan kepadamu. (Yang demikian itu) dengan tidak menghalalkan berburu ketika kamu sedang mengerjakan haji.Sesungguhnya Allah menetapkan hokum-hukum menurut yang dikehendaki-Nya. (QS. al-Maidah [5]: 1)

c. Firman Allah tentang perintah untuk saling tolong menolong dalam perbuatan positif, antara lain :

"Dan tolong-menolonglah kamu dalam (mengerjakan) kebajikan dan takwa, dan jangan tolong-menolong dalam berbuat dosa dan pelanggaran. Dan bertakwalah kamu kepada Allah, sesungguhnya Allah amat berat siksa-Nya" (QS. alMaidah [5]:2).

2. Hadis Nabi Muhamad

Hadis-hadis Nabi shallallahu alaihi wasallam tentang beberapa prinsip bermu'amalah, antara lain:

"Barang siapa melepaskan dari seorang muslim suatu kesulitan di dunia, Allah akan melepaskan kesulitan darinya pada hari kiamat; dan Allah senantiasa menolong hamba-Nya selama ia (suka) menolong saudaranya" (HR. Muslim dari Abu Hurairah).

"Perumpamaan orang beriman dalam kasih sayang, saling mengasihi dan mencintai bagaikan tubuh (yang satu); jikalau satu bagian menderita sakit maka bagian lain akan turut menderita" (HR. Muslim dari Nu'man bin Basyir)

3. Hukum positif di Indonesia

a. Undang Undang Nomor 40 tahun 2014 tentang Perasuransian

b. Fatwa DSN no 21 tahun 2001

\section{Perbedaan Asuransi Syariah dan Asuransi Konvensional}

Secara umum, ada beberapa perbedaan antara asuransi syariah dan konvensional, yakni : (Muhamad Syakir Sula, 2004 : 293-319).

\begin{tabular}{llll}
\hline No & Prinsip & Asuransi Syariah & Asuransi Konvensional \\
\hline 1 & Konsep & Perjanjian antara dua pihak & Sekumpulan orang yang \\
& & atau lebih, dimana pihak saling membantu, saling \\
& & penanggung mengikatkan menjamin, dan bekerja
\end{tabular}




\begin{tabular}{|c|c|c|c|}
\hline & & $\begin{array}{l}\text { diri kepada tertanggung } \\
\text { dengan menerima premi } \\
\text { asuransi untuk memberikan } \\
\text { pergantian } \\
\text { tertanggung }\end{array}$ & $\begin{array}{l}\text { sama, dengan cara } \\
\text { masing-masing } \\
\text { mengeluarkan dana } \\
\text { tabarru' }\end{array}$ \\
\hline 2 & Asal Usul & $\begin{array}{l}\text { Praktek Aqilah di dunia } \\
\text { Arab }\end{array}$ & $\begin{array}{l}\text { Perjanjian Hamurabi di } \\
\text { Babilonia }\end{array}$ \\
\hline 3 & $\begin{array}{l}\text { Sumber } \\
\text { Hukum }\end{array}$ & $\begin{array}{lrr}\text { Alquran, } & \text { Sunnah, } & \text { Ijma, } \\
\text { Istihsan, } & \text { Qiyas, } & \text { Fatwa } \\
\text { sahabat, } & \text { UrfMaslahah } \\
\text { Mursalah } & & \\
\end{array}$ & $\begin{array}{l}\text { Pikiran manusia dan } \\
\text { kebudayaan }\end{array}$ \\
\hline 2 & $\begin{array}{l}\text { Maisir, } \\
\text { Gharar, dan } \\
\text { Riba }\end{array}$ & $\begin{array}{l}\text { Tidak selaras dengan } \\
\text { syariah Islam karena adanya } \\
\text { maisir, gharar, serta riba yang } \\
\text { merupakan suatu yang } \\
\text { dilarang dalam muamalah }\end{array}$ & $\begin{array}{l}\text { Tidak mengandung unsur } \\
\text { maisir, gharar, serta riba }\end{array}$ \\
\hline 3 & $\begin{array}{l}\text { DPS (Dewan } \\
\text { Pengawas } \\
\text { Syariah) }\end{array}$ & Tidak mempunyai DPS & $\begin{array}{l}\text { Mempunyai DPS yang } \\
\text { berfungsi untuk } \\
\text { mengawasi pelaksanaan } \\
\text { operasional perusahaan } \\
\text { agar terhindar dari } \\
\text { praktek-praktek } \\
\text { muamalah yang } \\
\text { bertentangan dengan } \\
\text { prinsip-prinsip syariah }\end{array}$ \\
\hline 4 & Akad & $\begin{array}{l}\text { Akad jual beli, akad idz'aan, } \\
\text { akad gharar, serta akad } \\
\text { mulzim }\end{array}$ & $\begin{array}{l}\text { Akad tabarru' dan akad } \\
\text { tijarah }\end{array}$ \\
\hline 5 & $\begin{array}{l}\text { Jaminan } \\
\text { risiko }\end{array}$ & $\begin{array}{l}\text { Transfer of risk, dimana } \\
\text { adanya perpindahan risiko } \\
\text { dari tertanggung kepada } \\
\text { penanggung }\end{array}$ & $\begin{array}{l}\text { Sharing of risk, dimana } \\
\text { terjadi proses saling } \\
\text { menanggung antara satu } \\
\text { peserta dengan peserta } \\
\text { lainnya }\end{array}$ \\
\hline 6 & $\begin{array}{l}\text { Penggelolaan } \\
\text { dana }\end{array}$ & $\begin{array}{l}\text { Tidak ada pemisahan dana. } \\
\text { Ini akan berakibat pada } \\
\text { terjadinya dana hangus }\end{array}$ & $\begin{array}{l}\text { Pada produk saving (life) } \\
\text { terjadi pemisahan dana } \\
\text { yaitu dana tabarru', } \\
\text { derma, serta dana peserta } \\
\text { sehingga tidak mengenal } \\
\text { dana hangus. Sedangkan } \\
\text { untuk asuransi jiwa dan }\end{array}$ \\
\hline
\end{tabular}




\begin{tabular}{|c|c|c|c|}
\hline & & & $\begin{array}{l}\text { kerugian, semua dana } \\
\text { bersfat tabarru' }\end{array}$ \\
\hline 7 & Investasi & $\begin{array}{l}\text { Bebas melakukan investasi } \\
\text { dalam batas-batas ketentuan } \\
\text { perundang-undangan, dan } \\
\text { tidak dibatasi oleh hal halal } \\
\text { dan haramnya obyek atau } \\
\text { sistem investasi yang } \\
\text { digunakan }\end{array}$ & $\begin{array}{l}\text { Dapat melakukan } \\
\text { investasi sesuai dengan } \\
\text { ketentuan perundangan- } \\
\text { undangan dan tidak } \\
\text { bertentangan dengan } \\
\text { prinsip-prinsip syariah }\end{array}$ \\
\hline 8 & $\begin{array}{l}\text { Kepemilikan } \\
\text { dana }\end{array}$ & $\begin{array}{l}\text { Dana yang terkumpul dari } \\
\text { premi peserta seluruhnya } \\
\text { menjadi milik perusahaan. }\end{array}$ & $\begin{array}{l}\text { Dana yang terkumpul } \\
\text { dari peserta dalam bentuk } \\
\text { iuran atau kontribusi } \\
\text { merupakan milik peserta. } \\
\text { Perusahaan hanya } \\
\text { sebagai pemegang } \\
\text { amanah dalam mengelola } \\
\text { dana tersebut }\end{array}$ \\
\hline 9 & Unsur premi & $\begin{array}{l}\text { Unsur premi terdiri dari } \\
\text { tabel mortalitas, bunga, serta } \\
\text { biaya-biaya asuransi }\end{array}$ & $\begin{array}{l}\text { Iuran atau kontribusi } \\
\text { terdiri dari unsur tabarru' } \\
\text { dan tabungan (yang tidak } \\
\text { mengandung unsur riba). } \\
\text { Tabarru' juga dihitung } \\
\text { dari tabel mortalitas } \\
\text { tetapi tanpa perhitungan } \\
\text { bunga }\end{array}$ \\
\hline 10 & Loading & $\begin{array}{l}\text { Loading cukup besar } \\
\text { terutama } \\
\text { diperuntukkan untuk } \\
\text { komisi agen. Oleh sebab itu, } \\
\text { nilai tunai pada awal-awal } \\
\text { tahun biasanya kecil atau } \\
\text { belum ada }\end{array}$ & $\begin{array}{l}\text { Pada sebagian asuransi } \\
\text { syariah, } \\
\text { loading tidak dibebankan } \\
\text { pada peserta tetapi dari } \\
\text { pemegang saham. } \\
\text { Sedangkan sebagian yang } \\
\text { lainnya, mengambil } \\
\text { sekitar 20-30 persen dari } \\
\text { premi tahun pertama. } \\
\text { Dengan demikian nilai } \\
\text { tahun pertama sudah ada. }\end{array}$ \\
\hline 11 & $\begin{array}{l}\text { Sumber } \\
\text { pembayaran } \\
\text { klaim }\end{array}$ & Dari rekening perusahaan & Dari rekening tabarru \\
\hline 12 & $\begin{array}{l}\text { Sistem } \\
\text { akuntasi }\end{array}$ & $\begin{array}{l}\text { Memakai konsep akuntasi } \\
\text { accrual basis yaitu proses }\end{array}$ & $\begin{array}{rr} & \text { konsep } \\
\text { cash basis, }\end{array}$ \\
\hline
\end{tabular}




\begin{tabular}{|c|c|c|c|}
\hline & & $\begin{array}{l}\text { akuntansi yang mengakui } \\
\text { terjadinya peristiwa atau } \\
\text { keadaan non kas. Dan } \\
\text { mengakui aset, biaya, serta } \\
\text { hutang dalam jumlah yang } \\
\text { baru akan diterima dalam } \\
\text { waktu yang akan datang }\end{array}$ & $\begin{array}{l}\text { mengakui apa yang } \\
\text { benar-benar telah terjadi }\end{array}$ \\
\hline 13 & Keuntungan & $\begin{array}{l}\begin{array}{l}\text { Diperoleh dari } \\
\text { underwriting, }\end{array} \\
\text { reasuransi, serta } \\
\text { komisi } \\
\text { investasi yang dilakukan } \\
\text { perusahaan }\end{array}$ & $\begin{array}{l}\text { Diperoleh dari surplus } \\
\text { underwriting, komisi } \\
\text { reasuransi, serta hasil } \\
\text { investasi. Akan tetapi, } \\
\text { seluruh keuntungan itu } \\
\text { bukan milik perusahaan } \\
\text { karena harus dilakukan } \\
\text { bagi hasil (mudharabah) } \\
\text { dengan peserta }\end{array}$ \\
\hline 14 & $\begin{array}{l}\text { Misi } \\
\text { perusahaan }\end{array}$ & $\begin{array}{l}\text { Secara garis besar misi } \\
\text { utamanya adalah misi } \\
\text { ekonomi dan misi sosial }\end{array}$ & $\begin{array}{l}\text { Misinya adalah misi } \\
\text { aqidah, ibadah, ekonomi, } \\
\text { serta pemberdayaan umat }\end{array}$ \\
\hline
\end{tabular}

\section{PEMBAHASAN}

\section{Akad-Akad yang Terdapat Di Dalam Asuransi Syari'ah}

Asuransi syariah merupakan praktek tanggung menanggung diantara sesama peserta. Ketika salah satu peserta mengalami resiko yang dipertanggungkan, maka akan mendapat klaim yang berasal dari para peserta itu sendiri.

Secara umum, ketika peserta asuransi ikut dalam program perusahaan asuransi syariah akan di berikan akad, Akad yang diberikan harus sesuai dengan syariah yang tidak mengandung gharar (penipuan), maysir (perjudian), riba, zhulm (penganiayaan), risywah (suap), barang haram dan maksiat. Akad tersebut adalah :

\section{Akad Tijarah}

Akad tijarah adalah akad yang dilakukan untuk tujuan komersial. Bentuk akadnya menggunakan mudhorobah. Jenis akad tijarah dapat diubah menjadi jenis akad tabarru' bila pihak yang tertahan haknya, dengan rela melepaskan haknya sehingga menggugurkan kewajiban pihak yang belum menunaikan kewajibannya.

Akad tijarah ini adalah untuk mengelola uang premi yang telah diberikan kepada perusahaan asuransi syariah yang berkedudukan sebagai pengelola (Mudorib), sedangkan nasabahnya berkedudukan sebagai pemilik uang (shohibul mal). Ketika masa perjanjian habis, maka uang premi yang diakadkan dengan akad tijaroh akan dikembalikan 
beserta bagi hasilnya (Fatwa DSN No. 21/DSN-MUI/X/2001 tentang Pedoman Umum Asuransi Syari'ah).

\section{Akad Tabarru'}

Akad tabarru' adalah semua bentuk akad yang dilakukan dengan tujuan kebajikan dan tolong-menolong, bukan semata untuk tujuan komersial. Kemudian akad dalam akad tabarru adalah akad hibah dan akad tabarru' tidak bisa berubah menjadi akad tijaroh.

Dalam akad tabarru' (hibah), peserta memberikan hibah yang akan digunakan untuk menolong peserta lain yang terkena musibah. Sedangkan perusahaan bertindak sebagai pengelola dana hibah (Fatwa DSN No. 21/DSN-MUI/X/2001 tentang Pedoman Umum Asuransi Syari'ah).

Akad Tabarru' adalah Akad hibah dalam bentuk pemberian dana dari satu Peserta kepada Dana Tabarru' untuk tujuan tolong menolong di antara para Peserta, yang tidak bersifat clan bukan untuk tujuan komersial (Peraturan Menteri Keuangan Nomor 18/PMK.010/2010 Tentaang Penerapan Prinsip Dasar Penyelenggaraan Usaha Asuransi Dan Usaha Reasuransi dengan Prinsip Syariah).

Menurut fatwa Dewan Syari'ah Nasional No: 53/DSN-MUI/III/ 2006 Tentang Akad Tabarru' Pada Asuransi Syari'ah menyatakan, bahwa kedudukan para Pihak dalam akad tabarru' adalah ;

a. Dalam akad tabarru' (hibah), peserta memberikan dana hibah yang akan digunakan untuk menolong peserta atau peserta lain yang tertimpa musibah

b. Peserta secara individu merupakan pihak yang berhak menerima dana tabarru' (mu'amman/mutabarra' lahu, dan secara kolektif selaku penanggung (mu'ammin/mutabarri')

c. Perusahaan asuransi bertindak sebagai pengelola dana hibah, atas dasar akad wakalah dari para peserta selain pengelolaan investasi.

Akad Tobarru' wajib memuat sekurang-kurangnya :

a. kesepakatan para peserta untuk saling tolong menolong ( $\operatorname{tn}^{\prime}$ awuni)

b. hak dan kewajiban masing-masing peserta secara individu:

c. hak dan kewajiban peserta secara kolektif dalam kelompok

d. cara dan waktu pembayaran kontribusi dan santunan/ kl aim

e. ketentuan mengenai boleh atau tidaknya kontribusi ditarik kcmbali oleh peserta dalam hal terjadi pembatalan oleh peserta

f. ketentuan mengenai alternatif dan persentase pembagian Surplus Underwriting;

g. ketentuan lain yang disepakati (Peraturan Menteri Keuangan Nomor 18/PMK.010/2010 Tentaang Penerapan Prinsip Dasar 
Penyelenggaraan Usaha Asuransi Dan Usaha Reasuransi dengan Prinsip Syariah).

Untuk alad tijaroh dan akad tabarru' ini, ada beberapa akad yang mengkuti dalam pelaksanaannya. Akad-akad tersebut meliputi :

\section{Akad Wakalah bil Ujrah}

Akad Wakalah bil Ujrah adalah Akad Tijarah yang memberikan kuasa kepada Perusahaan sebagai wakil Peserta untuk mengelola Dana Tabarru' dan/ atau Dana Investasi Peserta, sesuai kuasa atau wewenang yang diberikan dengan imbalan berupa ujrah (fee). (Peraturan Menteri Keuangan Nomor 18/PMK.010/2010 Tentaang Penerapan Prinsip Dasar Penyelenggaraan Usaha Asuransi Dan Usaha Reasuransi dengan Prinsip Syariah).

Akad Wakalah bil Ujrah diperbolehkan dalam praktek asuransi syariah yang dilakukan antara perusahaan asuransi syariah dan peserta dimana posisi perusahaan asuransi syariah sebagai pengelola dan mendapatkan fee karena telah mendapatkan kuasa dari peserta.

Menurut fatwa Dewan Syari'ah Nasional No: 52/DSNMUI/III/2006Tentang Akad Wakalah Bil Ujrah Pada Asuransi Syari'ah Dan Reasuransi Syari'ah, objek Wakalah bil Ujrah meliputi antara lain:
a. kegiatan administrasi
b. pengelolaan dana
c. pembayaran klaim
d. underwriting
e. pengelolaan portofolio risiko
f. pemasaran
g. investasi

Akad Wakalnh bil Ujrah wajib memuat sekurang-kurangnya :

a. objek yang dikuasakan pengelolaannya

b. hak dan kewajiban peserta secara kolektif dan/atau peserta secara individu sebagai mutoakkil (pemberi kuasa)

c. hak dan kewajiban perusahaan sebagai toakil (penerima kuasa) termasuk kewajiban perusahaan untuk menanggung seluruh kerugian yang terjadi dalam kegiatan pengelolaan risiko dan/atau kegiatan pengelolaan nvestasi yang diakibatkan oleh kesalahan yang disengaja, kelalaian, atau wanprestasi yang dilakukan perusahaan

d. batasan kuasa atau wewenang yang diberikan peserta kepada perusahaan

e. besaran, cam, dan waktu pemotongan ujrah (fee)

f. ketentuan lain yang disepakati (Peraturan Menteri Keuangan Nomor 18/PMK.010/2010 Tentaang Penerapan Prinsip Dasar 
Penyelenggaraan Usaha Asuransi Dan Usaha Reasuransi dengan Prinsip Syariah).

Kedudukan dan ketentuan para pihak dalam Akad Wakalah bil Ujrah

a. Dalam akad ini, perusahaan bertindak sebagai wakil (yang mendapat kuasa) untuk mengelola dana

b. Peserta (pemegang polis) sebagai individu, dalam produk saving dan tabarru', bertindak sebagai muwakkil (pemberi kuasa) untuk mengelola dana

c. Peserta sebagai suatu badan/kelompok, dalam akun tabarru' bertindak sebagai muwakkil (pemberi kuasa) untuk mengelola dana

d. Wakil tidak boleh mewakilkan kepada pihak lain atas kuasa yang diterimanya, kecuali atas izin muwakkil (pemberi kuasa)

e. Akad Wakalah adalah bersifat amanah (yad amanah) dan bukan tanggungan (yad dhaman) sehingga wakil tidak menanggung risiko terhadap kerugian investasi dengan mengurangi fee yang telah diterimanya, kecuali karena kecerobohan atau wanprestasi.

f. Perusahaan asuransi sebagai wakil tidak berhak memperoleh bagian dari hasil investasi, karena akad yang digunakan adalah akad Wakalah (Fatwa Dewan Syari'ah Nasional No: 52/DSNMUI/III/2006Tentang Akad Wakalah Bil Ujrah Pada Asuransi Syari'ah Dan Reasuransi Syari'ah).

Pengelolaan investasi d a n Tabarru' atau dana Investasi peserta dengan Akad Wakalah bil Ujrah, perusahaan sebagai pengelola tidak berhak m en d a patk a n bagian dari hasil investasi tetapi hanya mendapatkan fee.

\section{Akad Mudharabah}

Akad Mudharabah adalah Akad tijarah yang memberikan kuasa kepada perusahaan sebagai mudharib untuk mengelola investasi dana tobarru' clan/atau dana investasi peserta, sesuai kuasa atau wewenang yang diberikan, dengan imbalan berupa bagi hasil (nisbah) yang besarnya telah disepakati sebelumnya.

Akad Mudharabah wajib memuat sekurang-kurangnya :

a. hak dan kewajiban peserta secara kolektif dan/atau peserta secara individu sebagai shnhibul mal (pemilik dana)

b. hak dan kewajiban perusahaan sebagai mudharib (pengelola dana)termasuk kewajiban perusahaan untuk menanggung seluruh kerugian yang terjadi dalam kegiatan pengelolaan investasi yang diakibatkan oleh kesalahan yang disengaja, kelalaian a tau wanprestasi yang dilakukan perusahaan

c. batasan wewenang yang diberikan peserta kepada perusahaan

d. bagi hasil (nisbnh), cara, dan waktu pembagian hasil investasi 
e. ketentuan lain yang disepakati (Peraturan Menteri Keuangan Nomor 18/PMK.010/2010 Tentaang Penerapan Prinsip Dasar Penyelenggaraan Usaha Asuransi Dan Usaha Reasuransi dengan Prinsip Syariah).

\section{Akad Mudharabah Musytarakah}

Akad Mudharabah Musytarakah aclalah Akad Tijarah yang memberikan kuasa kepada perusahaan sebagai mudharib untuk mengelola investasi Dana Tabarru' dan/ atau dana Investasi peserta, yang digabungkan dengan kekayaan perusahaan, sesuai kuasa atau wewenang yang diberikan dengan imbalan berupa bagi hasil (nisbah) yang besarnya ditentukan berclasarkan komposisi kekayaan yang digabungkan dan telah disepakati sebelumnya (Peraturan Menteri Keuangan Nomor 18/PMK.010/2010 Tentaang Penerapan Prinsip Dasar Penyelenggaraan Usaha Asuransi Dan Usaha Reasuransi dengan Prinsip Syariah).

Di dalam fatwa Dewan Syariah Nasional No: 51/DSNMUI/III/2006 Tentang Akad Mudharabah Musytarakah Pada Asuransi Syariah menyebutkan bahwa akad ini bisa dilakukan oleh perusahaan asuransi syariah karena merupakan bagian dari mudharabah dan merupakan gabungan dari akad Mudharabah dan Musytarakah.

Akad Mudharabah Musytarakah merupakan akad dimana modal perusahaan asuransi syariah dan nasabah digabungkan untuk diinvestasikan dan posisi perusahaan asuransi syariah sebagai pengelola.

Akad Mudharabah Musytarakah wajib memuat sekurang-kurangnya :

a. hak dan kewajiban peserta secara kolektif dan/atau peserta secara individu sebagai shahibul mal (pemilik dana)

b. hak dan kewajiban perusahaan sebagai mudharib (pengelola dana)termasuk kewajiban perusahaan untuk menanggung seluruh kerugian yang terjadi dalam kegiatan pengelolaan investasi yang diakibatkan oleh kesalahan yang disengaja, kelalaian atau wanprestasi yang dilakukan perusahaan

c. batasan wewenang yang diberikan peserta kepada perusahaan

d. cara dan waktu penentuan besar kekayaan peserta dan kekayaan perusahaan

e. bagi hasil (nisbah), cara, dan waktu pembagian hasil investasi

f. ketentuan lain yang disepakati ((Peraturan Menteri Keuangan Nomor 18/PMK.010/2010 Tentaang Penerapan Prinsip Dasar Penyelenggaraan Usaha Asuransi Dan Usaha Reasuransi dengan Prinsip Syariah).

Kedudukan para pihak dalam akad Mudharabah Musytarakah : 
a. Dalam akad ini, perusahaan asuransi bertindak sebagai mudharib (pengelola) dan sebagai musytarik (investor).

b. Peserta (pemegang polis) dalam produk saving, bertindak sebagai shahibul mal (investor).

c. Para peserta (pemegang polis) secara kolektif dalam produk non saving, bertidan bisa digunakan untuk produk tabungan maupun non tabungan.ndak sebagai shahibul mal (investor) (Fatwa Dewan Syariah Nasional No: 51/DSN-MUI/III/2006 Tentang Akad Mudharabah Musytarakah Pada Asuransi Syariah).

\section{KESIMPULAN}

Dari uraian di atas, maka dapat disimpulkan bahwa akad-akad yang melekat pada asuransi syariah adalah akad tijarah dan akad tabarru', sedangkan akad yang mengikuti akad tijarah maupun akad tabarru' adalah akad Mudharabah Musytarakah, akad Mudharabah dan akad Wakalah bil Ujrah.

\section{DAFTAR PUSTAKA}

Fatwa DSN No. 21/DSN-MUI/X/ 2001 tentang Pedoman Umum Asuransi Syari'ah

Fatwa Dewan Syariah Nasional No: 51/DSN-MUI/III/2006 Tentang Akad Mudharabah Musytarakah Pada Asuransi Syariah

Fatwa Dewan Syari'ah Nasional No: 52/DSN-MUI/III/2006Tentang Akad Wakalah Bil Ujrah Pada Asuransi Syari'ah Dan Reasuransi Syari'ah Fatwa Dewan Syari'ah Nasional No: 53/DSN-MUI/III/2006 Tentang Akad Tabarru'Pada Asuransi Syari'ah

Hasan Ali, 2004, Asuransi dalam Perspektif Hukum Islam, Kencana, Jakarta.

Muhammad Syakir Sula, (2004), Asuransi Syari'ah; Konsep dan Sistem Operasional, Gema Insani, Jakarta

Peraturan Menteri Keuangan Nomor 18/PMK.010/2010 Tentaang Penerapan Prinsip Dasar Penyelenggaraan Usaha Asuransi Dan Usaha Reasuransi dengan Prinsip Syariah

Undang Undang Nomor 40 tahun 2014 tentang Perasuransian 